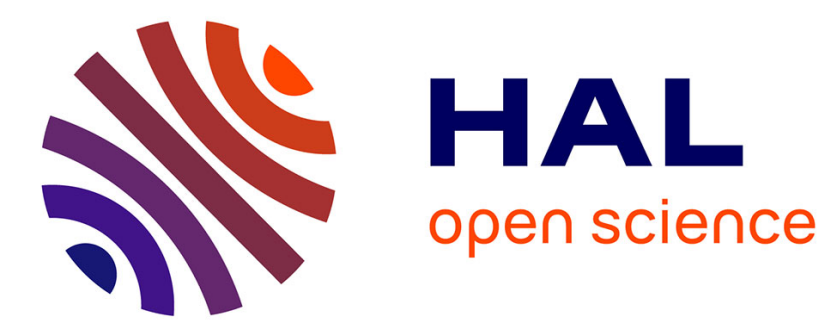

\title{
Review of Product-Service System Design Methods
}

Eugenia Marilungo, Margherita Peruzzini, Michele Germani

\section{To cite this version:}

Eugenia Marilungo, Margherita Peruzzini, Michele Germani. Review of Product-Service System Design Methods. 12th IFIP International Conference on Product Lifecycle Management (PLM), Oct 2015, Doha, Qatar. pp.271-279, 10.1007/978-3-319-33111-9_25 . hal-01377451

\section{HAL Id: hal-01377451 \\ https://hal.inria.fr/hal-01377451}

Submitted on 7 Oct 2016

HAL is a multi-disciplinary open access archive for the deposit and dissemination of scientific research documents, whether they are published or not. The documents may come from teaching and research institutions in France or abroad, or from public or private research centers.
L'archive ouverte pluridisciplinaire HAL, est destinée au dépôt et à la diffusion de documents scientifiques de niveau recherche, publiés ou non, émanant des établissements d'enseignement et de recherche français ou étrangers, des laboratoires publics ou privés.

\section{(c)(1)}

Distributed under a Creative Commons Attribution| 4.0 International License 


\title{
Review of Product-Service System Design methods
}

\author{
Eugenia Marilungo ${ }^{1}$, Margherita Peruzzini $^{2}$, Michele Germani $^{1}$ \\ ${ }_{4}^{1}$ Polytechnic University of Marche, via Brecce Bianche 12, 60131 Ancona \\ Tel $+3907 \overline{1} 2204 \overline{799}$, Tel +390712204969 , Fax. +390712204801 \\ [e.marilungo, m.germani]@ @m.univpm.it \\ ${ }^{2}$ University of Modena and Reggio Emilia, via Vivarelli $10,-4112 \overline{5}$, Modena \\ Tel. +39059 2056195, Fax. +390592056129. \\ margherita.peruzzini@unimore.it
}

Formatted: English (United States)

Formatted: English (United States)

\begin{abstract}
Many researchers have been recently approached the integration of products and services since its relevance in modern industrial scenarios. Despite several authors investigated such topics and defined methods to support companies in product-service ideation and design, they proposed methodologies tailored on specific issues: PSS assessment, requirements elicitation, functional modelling, etc. Anyway, neither of them has found an integration among almost of such methods. This paper presents a review of the current literature approaching PSS design and assessment along the last fifteen years. This due to there are different perspectives to frame PSS. According to this context, the paper gives an overview of PSS development in manufacturing industry, laying the groundwork for designers to develop an integrated tool able to incorporate some of the design methodologies and support manufacturing companies involved in the proposal of the PSS instead of traditional product.
\end{abstract}

Keywords: PSS (Product-Service System), PSS Sustainability, PSS design, PSS assessment, Business Model.

\section{Introduction}

During the last fifteen years many manufacturing companies approached the design and development of Product Service Systems (PSSs) instead of traditional products, in order to create new business opportunities and improve their product sustainability. According to this trend, several researchers investigated the pillars of PSS in different ways in order to support the designing and the assessing of PSSs in industry. It is proved that designing PSS represents a new perspective for traditional manufacturing companies, which conventionally establish their business on producing goods, to evolve their business model toward a service-oriented framework and adopt a new interpretation of the basic design concepts to embrace both product and services [1].

Indeed, in the modern scenario, companies need to change their current structures and processes that are unsuitable for mastering a new integrated offering. The develop-

Doha, Qatar, $19^{\text {th }}-21^{\text {h }}$ October 2015 
ment of a product-service solution raises new issues since the service component introduces further requirements to follow the customer needs, perceptions and preconceptions in a situated and changeable context, to encompass a life cycle perspective, and to fulfil the need for a more sustainable society [2].

A relevant stream of the literature, mainly rooted in the European research, has assigned an increasing emphasis to the role of PSS as a concrete response to these emerging pressures. The basic idea behind the PSS concept is that it pushes innovation strategy, shifting the business focus from the design and sales of physical products to the design and sales of a system consisting of products, services, supporting networks and infrastructures, which are jointly capable of fulfilling specific market demands. Furthermore, recent studies focused on new aspects that need to be considered from the earliest phases of design. Indeed, PSSs entails two important changes in company processes: firstly, traditional product lifecycle has to be enhanced by including also service management; secondly, the product-oriented company model must be extended to realize a service-oriented ecosystem [3]. Furthermore, Information and Communications Technologies (ICT) can be integrated to support sustainable business by the development of smart products, improved stakeholders communication, increased social inclusiveness, and consumer empowerment [4].

In a nutshell, creating PSSs entails two important changes in the company processes: firstly, traditional product lifecycle has to be enhanced by including also service management; secondly, the product-oriented company model must be extended to realize a service-oriented ecosystem [3]. Indeed, interrelations between physical products and intangible services are complex to model and manage; they require creating relationships with different stakeholders, where each partner is defined by means of its key resources and strategic factors [5]. In this context also the design of a global production network becomes an important capability to emerge in highly global competitive markets [6].

This paper aims at providing a review of the current literature approaching PSS along the last fifteen years in order to understand what are the main descriptions, methods and tools to support PSS design and development. This due to the several methods disseminated in literature and faced PSS design and assessment by different point of view, but without finding an integrated vision. Moreover, there are different perspectives to frame PSS. The paper gives an overview of PSS development in manufacturing industry, laying the groundwork for designers to develop an integrated tool able to incorporate some of the design methodologies and support manufacturing companies involved in the proposal of the PSS instead of traditional product.

\section{Product-Service System concept}

Several terms to identify the new trend of manufacturing companies to integrate product and service exist in literature (e.g. extended products, technical services, productservice systems (PSSs)). Anyway, they represent the same concept: a mix of tangible 
products and intangible services designed and combined to increase the value for customers $6[7]$. Value creation can be provided through an extended business network involving different stakeholders, which concur to create the services.

The PSS concept starts from the idea of the Extended Product [8], where intangible services are incorporated and integrated into a core product to add value for customers and improve company's profits and competitiveness. In particular, the common idea shift from consumers buying products towards consumers buying solutions and benefits, and this evolution can be represented along a linear axis like four different steps: 1) tangible product, 2) product and supporting services, 3) product and differentiating services, 4) product as a service. The steps 2 and 3 are defined also like Product+Service, and they mean the selling of product plus several services; while Product2Service (i.e. step 4) refers to selling only the services [9]. According to this view, PSS is current defined like a combination and integration of product and services into a system to deliver required functionalities in order to satisfy the customer needs [10], and it is able to produce synergies among profit, competitiveness, and environmental benefit.

The so defined PSS is composed by four main elements: the product, the related services, the ICT infrastructure required, and the partners' network to involve [11]. The main PSS variants are three and depend by the following perspectives [12]:

- Product-oriented, where the core is the product that has extra services delivered after product selling. The consumer acquires the product and uses services that the company offers, adding value to the product. Examples of this category can be represented by product maintenance, product monitoring, detergent supply.

- Use-oriented, where the product use is sold together with the services that add value to it, but the product itself remains the property of the company offering its use. Examples of this category can be represented by car-sharing or rental services.

- Result-oriented, that needs of a higher dematerialization of a product by including services. In this case, consumers buy a result or a competency and not the product. An example of this category can be the washed clothes in place of purchasing a washing machine product.

Some authors have presented real application of these PSS variants, while other authors shown different perspectives. For examples, Manzini and Vezzoli [1] have analysed PSS according three main characteristics [13]:

- $\quad$ Services providing value added to product lifecycle;

- $\quad$ Services providing final results to customer;

- $\quad$ Services providing enabling platforms to customers.

This classification can be compared with the previous ones, where services for final customers are the same of result-oriented, services to add product lifecycle are productoriented, and services enabling platforms to customers are used-oriented.

The PSS concept, regardless of its typology, can be translated in manufacturing industries like the application of technical service concept [14]. This means that manufacturing companies provide the physical product to customer; then, they deliver nonphysical product (i.e. services) to extend their business portfolio; finally, manufacturing 
companies provides its customers with highly tailored solutions, no longer distinguishing between product and services [15]. Moreover, technical services can be realized through the product-service life cycle management, in accordance to the specific customers' demand [16]. In order to design both product components and service functionalities in PSS design, manufacturing companies need to define a tailored partners' network; it involves both several stakeholders, like suppliers, ICT partners and customers [17]. Table 1 shows how several authors along the time have faced the PSS concept.

Table 1. PSS concept in literature review

\begin{tabular}{|c|c|}
\hline PSS concept & Authors \\
\hline Extended product & $\begin{array}{l}\text { Manzini and Vezzoli, } 2003 \text { [1]; } \\
\text { Brady et al., 2005 [18]; Wiesner et } \\
\text { al., } 2014 \text { [19] }\end{array}$ \\
\hline $\begin{array}{l}\text { PSS composed by: product, related services, ICT } \\
\text { infrastructure, and partners' network }\end{array}$ & $\begin{array}{l}\text { Goedkoop et al., } 1999 \text { [20]; Mont, } \\
2004 \text { [11] }\end{array}$ \\
\hline $\begin{array}{l}\text { Integration of product and service to reach cus- } \\
\text { tomer needs }\end{array}$ & $\begin{array}{l}\text { Mont, 2002 [14]; Brandstotter et al., } \\
2003 \text { [21]; Aurich et al., } 2010 \text { [10] }\end{array}$ \\
\hline $\begin{array}{l}\text { PSS typology: product-oriented, use-oriented, re- } \\
\text { sult-oriented }\end{array}$ & $\begin{array}{l}\text { Tukker, } 2004 \text { [12]; Baines et al., } \\
2007 \text { [22]; Alix and Zacharewicz, } \\
2012 \text { [13] }\end{array}$ \\
\hline Technical services & $\begin{array}{l}\text { Mont, } 2002 \text { [14]; Aurich et al., } 2006 \\
\text { [23] }\end{array}$ \\
\hline PSS to reduce the environmental impacts & $\begin{array}{l}\text { Brandstotter et al., } 2003[21] \\
\text { Baines et al., } 2007 \text { [22] }\end{array}$ \\
\hline
\end{tabular}

\section{Formatted: German (Austria)}

\section{Product-Service System design methodologies}

Usually manufacturing companies have a well-defined and structured product development process, but they lack a sufficiently defined service development process as found in traditional service companies. As consequence, they are poorly equipped with appropriate approaches, methodologies and tools for support in efficient way the development of PSSs.

In literature, several methods have been proposed to manage PSS along the entire lifecycle [24]. Some of them are very theoretical and hard to implement in practice, others are very specific and have a limited applicability range. Table 2 shows an overview of the main methods faced by different authors that deal with PSS design.

Requirement Elicitation (RE) is a crucial method to adopt during the design process of a PSS, in order to identify the main requirements according to the target market. Indeed, offering PSS instead traditional product requires additional competencies to identify the service functionalities to enhance the product, and a better understanding of the customer requirements to reach [25]. This implies a huge quantity of implicit knowledge to be elicited and a big variety of actors to involve [26]. 
Recent studies about the application of RE in PSS design in order to investigate the customer needs propose the following approaches:

- multi-level analysis or the Design Structure Matrix (DSM), that can be used to define the main PSS functions;

- Business Use Cases (BUCs) analysis, which define the use-case model and a goal-oriented set of interactions between external actors and the system under consideration [3];

- Serious Games to elicit PSS requirements and investigate the PSS lifecycle [26];

- Quality Functional Deployment (QFD) technique [27] that allows mapping the customer needs with the PSS functions to elicit the final PSS requirements for the solution to be developed by the correlation by means of a sequence of Houses of Quality (HoQ).

The combination of these techniques with a deep process analysis and related modelling allows achieving a comprehensive mapping of the PSS to develop. Indeed, process analysis and modelling allow defining the main activities to achieve the process tasks, and identifying the enterprise's ability in capturing and sharing process knowledge and transferring it. The main common techniques for process modelling come from static modelling focusing on the flow of information (i.e. UML, Petri- Nets, flowcharting, IDEF0, etc.), to dynamic modelling for process evaluation (i.e. EventProcess Chain) [28]. They are useful for process representation and performance evaluation, providing a high-technical view.

Table 2. PSS design methods

\begin{tabular}{|c|c|c|}
\hline \multicolumn{2}{|c|}{ PSS Design methods } & \multirow{2}{*}{$\begin{array}{l}\text { Authors } \\
\text { Van Halen et al., } 2005 \text { [29] }\end{array}$} \\
\hline System & MePSS & \\
\hline & Service Engineering & $\begin{array}{l}\text { Arai and Shimomura, } 2004 \text { [30]; Shimomura } \\
\text { and Tomiyarna, } 2005 \text { [31]; Sakao and } \\
\text { Shimomura, } 2007 \text { [32] }\end{array}$ \\
\hline & Agent-Based model & Maisenbacher et al., 2014 [33] \\
\hline & Blueprinting & Geum and Park, $2011[34]$ \\
\hline & $\begin{array}{l}\text { Quality Functional De- } \\
\text { ployment (QFD) }\end{array}$ & $\begin{array}{l}\text { Thompson, } 2005 \text { [27]; Marilungo et al., } \\
2015 \text { [35] }\end{array}$ \\
\hline \multirow[t]{3}{*}{ Service } & Requirements elicitation & Miller et al., 2002 [25] \\
\hline & $\begin{array}{l}\text { Business Use Cases } \\
\text { (BUCs) }\end{array}$ & Peruzzini et al., 2012 [3] \\
\hline & Serious Games & Wiesner et al., 2012 [26] \\
\hline
\end{tabular}

The development of a PSS necessarily requires the creation of a structured network of partners and stakeholders, able to exploit the necessary tangible and intangible assets and create valuable solutions to share among all partners. This means moving from the traditional concept of manufacturing enterprise to the new idea of Virtual Manufacturing Enterprise (VME) [36] or Global Production Network (GPN). They would repre- 
sent an aggregation of several partners with different knowledge and capabilities, focused on the realization of a specific PSS idea. Moreover, the VME and GPN imply the definition of a proper Business Model in order to recognize the strategic factors for each partner as well as the key resources and activities to involve in the new PSS scenario to develop [5].

\section{Product-Service System assessment}

According to the PSS definition, it could provide not only a higher customer satisfaction [16], but also a great advantage on the sustainability [37], according to its three main dimensions: economy, environment, and social wellbeing [38]. Indeed, from the economic viewpoint, PSSs can create new market potentials and higher profit margins, and can contribute to higher productivity by means of reducing investment costs along the lifetime as well as reducing operating costs for the final users [39]. From an environment viewpoint, PSSs can be more efficient thanks to a more conscious product usage, increased resource productivity and a close loop-chain manufacturing [40]. Finally, PSSs can be also socially advanced, as services able to build up and secure knowledge intensive jobs and able to contribute to a more geographically balanced wellbeing distribution [41]. However, the biggest challenge is carrying out a reliable sustainability assessment for PSS in order to identify the most sustainable solution to offer to customers.

In manufacturing industry, product sustainability can be achieved by adopting lifecycle design approach: it allows quantifying product impacts and providing tangible commercial values in terms of efficiency and costs [42]. They are based on the definition of several indicators to assess the lifecycle performance and support comparative analysis. Some techniques to support this described lifecycle design approach are the Life Cycle Assessment (LCA) [43], in order to evaluate the environmental impacts, and the Life Cycle Cost Assessment (LCCA) [44], in order to recognize all the economic impact during the product lifecycle. In recent times, also the social impacts have been included in the lifecycle design approach by the so-called Social Life Cycle Assessment (SLCA) [45].

Recently, some researches apply the sustainability issue also to the PSS [14], [46], but they do not adopt lifecycle approaches. Instead, other researches propose to translate a lifecycle design approach to PSS [47], [48], [49]: they have demonstrated how to assess the sustainability impacts of an integrated PSS by considering not only the impacts related to the product realization, usage and dismissing, but involving also the intangible assets and the ecosystem actors.

According to the aim of supporting designer, another tool can be useful to assess PSS at design stage. It consists in Business Process Modelling (BPM) technics that are the most appropriate to analyse the scenario to develop. It can be considered as conceptual tools able to support industrial companies to identify, understand, design, analyse, and change their current Business Models (BM) [50]. In the context of product servitization, the development of PSS forces product-centric firms to innovate their current business model and evolve their own processes, and for this reason they need to have 
support in defining and adopting the new BM in order to develop the designed PSS. This issue represents a challenge for industrial companies and offers opportunities for investigation [51].

In literature, several research studies identify the same method to develop a new BM for a PSS; it involves four main research steps [52]:

- Identification of PSS characteristics and typology;

- Investigation of business model concepts;

- Development of the framework;

- Application of the developed framework by means of a case study.

Such approach was used also by Barquet et al. [52] to develop a framework for industrial company able to define the adoption of PSS. Other authors, like [13], face that the main pillars to define a PSS Business Model require involving: the value proposition to offer in the market, the management of communication and distribution channels, and the software infrastructure, the definition of financial aspects.

\section{Discussion and Conclusions}

The present paper provides a comprehensive review of the latest researches about PSS design methodologies and assessment approach. The added value of this work is its focus on designers and manufacturing companies since It aims to understand how the PSS topic is extended in industry and which are challenges and issues to face in design.

There is a lack of integrated tools able to support traditional manufacturing industries to implement PSS and support designers in PSS development process. Moreover, PSS assessment is usually carried out after the product design and is not integrated directly with the service design phase and service knowledge; furthermore experience regarding PSS business models is limited. A typical problem consists of lack of information sharing and management of product-service relations. According to this discussion, the literature review highlights how designing and developing a new methodology to create a close-loop between design and assessment phases along the PSS lifecycle is required.

\section{References}

1. Manzini E., Vezzoli C.: A strategic design approach to develop sustainable product service systems: examples taken from the 'environmentally friendly innovation' Italian prize. J. Clean. Prod. 11, 851--857 (2003)

2. Cavalieri S, Pezzotta, G.: Product-Service Systems Engineering: State of the art and research challenges. Computer in Industry, vol. 63(4), pp.278--288 (2012)

3. Peruzzini M., Germani M., Favi C.: Shift from PLM to SLM: A method to support business requirements elicitation for service innovation in Product Lifecycle Management. In: IFIP Advances in Information and Communication Technology 388 AICT, pp. 111-123. Springer New York (2012)

4. Hernández Pardo R.J., Bhamra T., Bhamra R.: Sustainable Product Service Systems in Smal and Medium Enterprises (SMEs): Opportunities in the Leather Manufacturing Industry. Sustainability 4(2), 175--192 (2012) 
5. Ghaziani A, Ventresca M.: Keywords and cultural change: Frame analyses of Business Model public talk, 1975 to 2000. Sociological Forum, vol. 20(4), pp. 523--529 (2005)

6. Peppard J., Rylander A.: From Value Chain to Value Network: Insights for Mobile Operators. European Management Journal 24(2-3), 128--141 (2006)

7. Furrer O.: Le rôle stratégique des services autour des produits. Revue Française de Gestion 113, 98--108 (2007)

8. Thoben K.D., Jagdev H., Eschenbaecher J.: Extended Products: Evolving Traditional Product Concepts. In: 7th International Conference on Concurrent Enterprising, Bremen (2001)

9. Hippel E.: Democratizing Innovation. MIT Press (2005)

10.Aurich J.C., Mannweiler E., Schweitzer E.: How to design and offer services successfully. In: CIRP Journal of Manufacturing Science and Technology. doi:10.1016/j.cirpj.2010.03.002 (2010)

11.Mont O.: What is behind meagre attempts to sustainable consumption? Institutional and product-service systems perspective, In: Proceedings of the international workshop, driving forces and barriers to sustainable consumption, Leeds, UK (2004)

12.Tukker A.: Eight types of product-service system: eight ways to sustainability? Experiences from SusProNet. Business Strategy and the Environment 13(4), 246--260 (2004)

13.Alix T., Zacharewicz G.: Product-service systems scenarios simulation based on GDEVS/HLA: Generalized discrete event specification/high level architecture. Comp. in Ind. 63, 370--378 (2012)

14.Mont O.: Clarifying the concept of product-service system. J. Clean. Prod. 10(3), 237--245 (2002)

15.Schuh G, Friedli T, Gebauer H.: Fit for Service e Industrie als Dienstleister. Munchen Wien: Hanser $(\overline{200} \overline{4})$

16.Aurich J.C., Fuchs C., Wagenknecht C.: Life cycle oriented design of technical Product-Service Systems. J. Clean. Prod. 14, 1480--1494 (2006)

17.Kimita K, Shimomura Y.: Development of the Design Guideline for Product-Service Systems. In: 6th CIRP International Conference on Industrial Product-Service Systems, Windsor, Canada (2014)

18.Brady T., Davies A., Gann D.M.: Creating value by delivering integrated solutions. International Journal of Project Management, vol. 23(5), pp. 360--365 (2005)

19.Wiesner S., Padrock P., Thoben K.D.: Extended Product Business Model development in four manufacturing case studies. In: 6th CIRP International Conference on Industrial Product-Service Systems, vol. 16, pp. 110 - 115, Windsor, Canada (2014)

20.Goedkoop M.J., van Halen C.J.G., te Riele H.R.M., Rommens P.J.M.: Product Service Systems, Ecological and Economic Basics. Report for Dutch Ministries of Environment (VROM) and Economic Affairs (EZ) (1999)

21.Brandstötter M., Haberl M., Knoth R., Kopacek B., Kopacek P.: IT on demand- towards an environmental conscious service system for Vienna. In: Proceedings of EcoDesign'03: Third International Symposium on Environmentally Conscious Design and inverse Manufacturing, pp. 799-802, Japan (2003)

22.Baines T.S., Lightfoot H.W., Evans S., Neely A., Greenough R., Peppard J., Roy R., Shehab E., Braganza A., Tiwari A., Alcock J.R., Angus J.P., Bastl M., Cousens A., Irving P., Johnson M., Kingston J., Lockett H., Martinez V., Michele P., Tranfield D., Walton I.M., Wilson H.: State-of-the-art in product-service systems. Proceedings of the Institution of Mechanical Engineers, Part B: Journal of Engineering Manufacture, vol. 221(10), pp. 1543-1552 (2007)

23. Aurich J.C., Fuchs C., Wagenknecht .: Life cycle oriented design of technical Product-Service Systems. J. Clean. Prod., vol. 14(17), pp. 1480-1494 (2006)

24.Garetti M., Rosa P., Terzi S.: Life Cycle Simulation for the design of Product-Service Systems. Comp. in Ind. 63, 361--369 (2012)

25.Miller D., Hope Q., Eisenstat R., Foote N., Galbraith J.: The problem of solutions: balancing clients and capabilities, Business Horizon 45(2), 3--12 (2002) 
26.Wiesner S., Peruzzini M., Doumeingts G., Thoben K.D.: Requirements Engineering for Servitization in Manufacturing Service Ecosystems (MSEE). In: 4th CIRP IPS2 Conference, Japan (2012)

27.Thompson K.: A taxonomy of virtual business networks, The Bumble Bee (2005)

28.Cohen L.: Quality Function Deployment, How to Make QFD Work for You, Addison-Wesley (1995)

29.Halen C.V., Vezzoli C., Wimmer R.: Methodology for Product Service System Innovation. How to Implement Clean, Clever and Competitive Strategies in European Industries. Royal Van Gorcum., Assen, Netherlands (2005)

30.Arai T., Shimomura Y.: Proposal of Service CAD System - A Tool for Service Engineering, Annals of the CIRP, vol. 53(1), pp. 397 (2004)

31. Shimomura Y., Tomiyama T.: Service Modeling for Service Engineering, IFIP International Federation for Information Processing, vol. 167, pp. 31 (2005)

32. Sakao T., Shimomura Y.: Service Engineering: a novel engineering discipline for producers to increase value combining service and product. J. Clean. Prod., vol. 15(6), pp. 590--604 (2007)

33. Maisenbachera S., Weidmanna D., Kaspereka D., Omer M.: Applicability of Agent-Based Modeling for Supporting Product-Service System Development. Proceedings of the 6th CIRP Conference on Industrial Product-Service Systems, vol. 16, pp. 356--361 (2014)

34. Geum Y., Park Y.: Designing the sustainable product-service integration: a product-service blueprint approach. Journal of Cleaner Production, vol. 19, pp. 1601--1614 (2011)

35. Marilungo E., Peruzzini M., Germani M.: An integrated method to support PSS design within the Virtual Enterprise. 7th Industrial Product-Service Systems Conference, Saint Etienne, France (2015)

36. Patel N., Hlupic V.: Dynamic Business Process Modelling (BPM) for business process change. International Journal of Simulation Systems, Science and Technology 2(2), 51--64 (2001)

37. McAloone T.C., Mougaard K., Restrepo J., Knudsen S.: Eco-innovation in the value chain. In: Internation design conference, Bubrovinik, Croatia (2010)

38. Adams W.M.: The Future of Sustainability: Re-thinking Environment and Development in the Twenty-first Century. Technical report, IUCN Renowned Thinkers Meeting (2006)

39. Baines T.S., Lightfoot H., Evans S., Neely A., Greenough R., Peppard J., Roy R., Shehab E., Braganza A., Tiwari A., Alcock J.R., Angus J.P., Bastl M., Cousens A., Irving P., Johnson M., Kingston J., Lockett H., Martinez V., Michele P., Tranfield D., Walton I.M., Wilson H.: State of the art in Product-Service System, Journal of Engineering Manufacture 221, 1543--1552 (2007)

40. Favi C., Peruzzini M., Germani M.: A lifecycle design approach to analyse the eco-sustainability of industrial products and product-service systems. In: International Design Conference, Marjanovic, Storga, Pavkovic, Bojcetic (eds.), pp. 879--888 (2012)

41. Stahel W.: The Utilization-Focused Service Economy, Resource Efficiency and ProductLife Extension. In: Allenby B., Richard, D. (eds.) The greening of industrial ecosystem, Washington, DC: National Academy Press, pp. 178--190 (1994)

42. Jeswiet J.: A definition for life cycle engineering. In: 36th International seminar on manufacturing systems, Saarbrucken, Germany (2003)

43. ISO 14040:2006 Environmental Management - Life Cycle Assessment - Principles and Framework (2006)

44. Woodward D.G.: Life cycle costing - theory, information acquisition and application. J. Project Management 15(6), 335--344 (1997)

45. Weidema B.: The integration of economic and social aspects in life cycle impact assessment. J. Life Cycle Assess 11(1), 89--96 (2006)

46. Young G.: Design thinking and sustainability (2010) 
47. Peruzzini M., Germani M., Marilungo E.: A sustainability lifecycle assessment of products and services for the Extended Enterprise evolution. In: 10th International Conference on Product Lifecycle Management (2013)

48. Peruzzini M., Marilungo E., Germani M.: Product-Service Sustainability Assessment in Virtual Manufacturing Enterprises. In: PRO-VE conference (2013)

49. Kwak M., Kim H.: Economic and Environmental Impacts of Product Service Lifetime: A Life-Cycle perspective. In: 5th CIRP International Conference on Industrial Product-Service Systems, Bochum, Germany (2013)

50. Osterwalder A., Pigneur Y., Tucci C.L.: Clarifying business models: Origins, present and future of the concept. Communications of the Association for Information Systems 15, 1-40 (2005)

51. Mont O.: Product-service system: Panacea or myth? (Doctoral thesis). Retrieved from the National Library of Sweden database 91-88902-33-1 (2004)

52. Barquet A.P.B., de Oliveira M.G., Amigo C.R., Cunha V.P., Rozenfeld H.: Employing the business model concept to support the adoption of product-service systems (PSS). Industrial Marketing Management 42, 693--704 (2013) 